\title{
Growth Trends in Area Production and Productivity of Total Horticultural Crops in India (Haryana and Odisha states)
}

\author{
Mousumi Priyadarshini ${ }^{*}$, KK Kundu ${ }^{2}$ and Dalip Kumar Bishnoi ${ }^{2}$ \\ ${ }^{1}$ Division of Agril. Economics, ICAR-IARI, Delhi, India \\ ${ }^{2}$ Department of Agril. Economics, CCSHAU, Hisar, Haryana, India \\ *Corresponding author
}

\section{A B S T R A C T}

\begin{tabular}{|l|}
\hline Ke y w o r d s \\
CAGR, Area, \\
Production, \\
Productivity, \\
Horticultural crops, \\
Fruits, Vegetables \\
\hline Article Info \\
\hline $\begin{array}{l}\text { Accepted: } \\
\text { 22 June 2020 } \\
\text { Available Online: } \\
\text { 10 July } 2020\end{array}$ \\
\hline \hline
\end{tabular}

\section{Introduction}

In India the need for horticulture development was first time recognised during the $4^{\text {th }}$ fiveyear plan (1969-74), but during that time there was a need to increase the food grain production (Chand et al., 2008). Over the past two decades horticulture sector has developed as a prominent sector in agriculture scenario by contributing a lot to the overall economic growth. Besides providing nutritional and health benefits, it provides a wide range of options for sustainable rural economy through diversification. It provides a good scope for value addition in both production and post- harvest management like marketing and processing through a better supply chain management. The diverse agro climatic conditions of India made itself conducive for cultivation of almost all horticulture crops like fruits, vegetables, flowers, medicinal, aromatics and plantation crops. Realising the importance of horticulture sector Govt of India started giving more attention towards development of horticulture sector from $7^{\text {th }}$ five-year plan with significant budgetary allocation from $8^{\text {th }}$ five-year plan onwards. Department of Agriculture, Co-operation and Farmers Welfare of Ministry of Agriculture is the nodal agency for over viewing 
horticulture development in the country. Considering the importance of horticulture sector in 2011-12, government of India had announced 2012 as the "Year of Horticulture".

India is the second largest producer of fruits and vegetables in the world after China. In the year 2017-18 the total horticultural production in India was 311.71 million tonnes from an area of 25.4 million hectares. India produces about 184.39 million tonnes $(59.15 \%$ of total horticultural production) of vegetables from 10.25 million hectares $(40.34 \%)$ of land and 97.35 million tonnes $(31.23 \%$ of total horticultural production) of fruits from an area of 6.5 million hectares (National Horticulture Board). Horticultural sector contributes to about 30 per cent of Indian agricultural GDP from 13.08 per cent area (National Horticulture Board). Keeping in mind all these facts the present study is conducted to see the growth trends in area, production and productivity of total horticultural crops in India and two states i.e. Haryana and Odisha.

\section{Materials and Methods}

For the present study trend analysis in area, production and productivity of total horticultural crops, fruits and vegetables was done for Haryana, Odisha and India. The two states were taken purposively for the analysis. Secondary data regarding area production and productivity of the horticultural crops for India, Haryana and Odisha states were collected from various published sources and unpublished sources like National Horticulture Board, statistical abstracts and Departments of Horticulture, Government of Haryana and Government of Odisha from 2005-06 to 2017-18. The CGR was then calculated to show the trends in area, production and productivity. The growth rates were estimated using exponential growth functional form as under:
$Y=A B^{t} U_{t}$,

Taking $\log$ i.e.,

$\log \mathrm{Y}=\log \mathrm{A}+\mathrm{t} \log \mathrm{B}+\log \mathrm{U}_{\mathrm{t}}$

i.e. $y=a+b t+u_{t}$

Where,

$\mathrm{y}=$ area or production or yield,

$\mathrm{a}=$ constant,

$\mathrm{b}=$ regression coefficient,

$\mathrm{u}_{\mathrm{t}}=$ disturbance term

And $\mathrm{t}=$ time in years starting from the base year 2005-06.

The compound growth rate (Antilog of b-1) * 100 was used to calculate the growth rates in area, production and productivity for a period of 13 years.

\section{Results and Discussion}

Trends in area, production and productivity of total horticultural crops in India, Haryana and Odisha

It is evident from the Table 1 that in the period (2005-2017), the area, production and productivity of total horticultural crops showed an increase by $31.58,84.89$ and 40.48 per cent, respectively in the year 2017-18 over the area, production and productivity under total horticultural crops in the year 2005-06 in India. The compound growth rate in area, production and productivity of total horticultural crops for India were recorded as $2.39,4.76$ and 2.32 per cent, respectively. The production of total horticultural crops showed increasing trend over the time period 2005-18. Nabi et al., (2017) and Jha et al., (2019) also revealed similar kind of positive growth rate in area, production and productivity of total horticultural crops in India. During the period (2005-2017), the area, production and productivity of total horticultural crops showed increase by $92.50,145.77$ and 27.66 per cent, respectively in the year 2017-18 over the area, production and productivity under total horticultural crops in the year 
2005-06 in Haryana. The compound growth rate in area, production and productivity of total horticultural crops in Haryana were recorded as 5.08, 7.55 and 2.34 per cent respectively. The area and production of total horticultural crops showed increasing trend over the time period 2005-18. However, the productivity has not shown any specific trend. Similar kinds of results were reported by Tuteja (2011). During the period (2005-2017), the area, production and productivity of total horticultural crops showed increase by 13.96 , 18.56 and 4.09 per cent, respectively in the year 2017-18 over the area, production and productivity under total horticultural crops in the year 2005-06 in Odisha. The compound growth rate in area, production and productivity of total horticultural crops in Odisha were recorded as $0.91,1.66$ and 0.75 per cent respectively. Chand et al., (2008) also found a positive growth rate in output of horticultural sector in Odisha. From the table 1 it is evident that Odisha has more area and production of horticultural crops than that of Haryana. But in case of productivity Haryana has more productivity than that of Odisha. The growth rate in area, production and productivity of total horticultural crops in Haryana was found to be more than that of Odisha.

\section{Trends in area, production and productivity of vegetables in India, Haryana and Odisha}

Table 2 shows the trends in area, production and productivity of vegetables in India, Haryana and Odisha. The CAGR in area production and productivity of vegetables in India was found to be $3.11,4.28$ and 1.14 percent respectively. Whereas for the state Haryana the same values were found to be 4.76, 7.11 and 2.24 percent respectively. In Odisha the CAGR in area, production and productivity of vegetables was found to be $0.14,1.02$ and 0.88 percent respectively. The percentage change in area and production over 2005-06 was found to be more in Haryana $(92.13 \%, 139.60 \%)$ than that of India $(42.23 \%, 65.53 \%)$ and Odisha $(1.56 \%$, $12.27 \%$ ). Sharma et al., (2019) also found positive trend in area, production of vegetables in Haryana.

Trends in area, production and productivity of total fruit crops in India, Haryana and Odisha

Table 3 shows trends in area, production and productivity of total fruit crops in Haryana, Odisha and India. The CAGR in area, production and productivity of total fruit crops in India was found to be 1.41,4.56 and 3.11 percent respectively. For Haryana the CAGR in area, production and productivity of fruits was found to be 7.39, 12.90 and 5.14 percent respectively. Whereas for Odisha these values for were found to be $2.87,5.02$ and 2.09 percent respectively. The percentage change in area and production of fruit crops of 2017-18 over 2005-06 were found to be more in Haryana $(136.14 \%, 235.9 \%)$ than that of India $(22.2 \%, 75.88 \%)$ and Odisha $(43.34 \%, 71.18 \%)$.

Conclusions and policy implications are as follows:

Indian agriculture is generally marked with low profit and the farm income generated is not sufficient to provide a livelihood (Chand et al., 2011). So, to double the farmer's income diversification towards high value horticultural crops will be good. From this study it has been found that both in all India level and state level the area and production under horticultural crops is increasing but the productivity is very less. So better availability of better-quality planting material, mechanization, quality research and development, more public and private sector investments in this sector will be of great use. 
Table.1 Trends in area, production and productivity of total horticultural crops in India

\begin{tabular}{|c|c|c|c|c|c|c|c|c|c|}
\hline \multirow[t]{2}{*}{ Years } & \multicolumn{3}{|c|}{ India } & \multicolumn{3}{|c|}{ Haryana } & \multicolumn{3}{|c|}{ Odisha } \\
\hline & $\begin{array}{c}\text { Area } \\
(' 000 \text { ha })\end{array}$ & $\begin{array}{l}\text { Production } \\
\text { ('000T) }\end{array}$ & $\begin{array}{c}\text { Productivity } \\
\text { (tonnes/ha) }\end{array}$ & $\begin{array}{c}\text { Area } \\
\text { ('000ha) }\end{array}$ & $\begin{array}{l}\text { Production } \\
\text { ('000T) }\end{array}$ & $\begin{array}{l}\text { Productivity } \\
\text { (tonnes/ha) }\end{array}$ & $\begin{array}{c}\text { Area } \\
(' 000 \text { ha })\end{array}$ & $\begin{array}{l}\text { Production } \\
\text { ('000T) }\end{array}$ & $\begin{array}{c}\text { Productivity } \\
\text { (tonnes/ha) }\end{array}$ \\
\hline $2005-06$ & 19327.4 & 168598.7 & 8.72 & 277.4 & 3292.4 & 11.87 & 1211.1 & 9936.6 & 8.2 \\
\hline 2006-07 & 19392.8 & 191831.3 & 9.89 & 323.5 & 3706.5 & 11.46 & 1239.3 & 10080.1 & 8.13 \\
\hline 2007-08 & 20207.2 & 211234.2 & 10.45 & 320.4 & 3618 & 11.29 & 1257.4 & 9975.9 & 7.93 \\
\hline 2008-09 & 20661.6 & 214715.9 & 10.39 & 347.7 & 4245.7 & 12.21 & 1300.1 & 10506.9 & 8.08 \\
\hline 2009-10 & 20875.7 & 223089 & 10.69 & 354.7 & 4386.7 & 12.37 & 1346.1 & 11306.9 & 8.4 \\
\hline $2010-11$ & 21824.1 & 240426 & 11.02 & 415 & 5144.7 & 12.4 & 1207.8 & 10298.5 & 8.53 \\
\hline 2011-12 & 23242 & 257277.2 & 11.07 & 424.7 & 5671.94 & 13.36 & 1363.9 & 12243.18 & 8.98 \\
\hline 2012-13 & 23694.14 & 268847.5 & 11.35 & 434.2 & 5676.06 & 13.07 & 1369.09 & 12245.72 & 8.94 \\
\hline 2013-14 & 24198.5 & 277352 & 11.5 & 448.1 & 6285.5 & 14 & 1353.6 & 12169 & 9 \\
\hline 2014-15 & 23410 & 280986.1 & 12 & 442.2 & 6164.4 & 13.9 & 1359.6 & 12145.1 & 8.9 \\
\hline 2015-16 & 23787.34 & 283360.3 & 11.91 & 494.2 & 7053.84 & 14.27 & 1284.37 & 11119.92 & 8.66 \\
\hline 2016-17 & 24850.86 & 300643 & 12.1 & 495.23 & 7093.26 & 14.32 & 1369.74 & 11800.21 & 8.61 \\
\hline 2017-18 & 25431 & 311714 & 12.25 & 534 & 8091.7 & 15.153 & 1380.2 & 11781 & 8.54 \\
\hline Average & 22377.13 & 248467.31 & 11.03 & 408.56 & 5417.75 & 13.05 & 1310.95 & 11200.69 & 8.53 \\
\hline $\begin{array}{l}\text { Percentage change } \\
\text { over 2005-06 }\end{array}$ & 31.58 & 84.89 & 40.48 & 92.50 & 145.77 & 27.66 & 13.96 & 18.56 & 4.09 \\
\hline CAGR & 2.39 & 4.76 & 2.32 & 5.08 & 7.55 & 2.34 & 0.91 & 1.66 & 0.75 \\
\hline
\end{tabular}

(Source: National Horticulture Board, Department of Horticulture, Govt. of Haryana Department of Horticulture, Govt. of Odisha) 
Table. 2 Trends in area, production and productivity of vegetables in India, Haryana and Odisha

\begin{tabular}{|c|c|c|c|c|c|c|c|c|c|}
\hline \multirow[t]{2}{*}{ Years } & \multicolumn{3}{|c|}{ India } & \multicolumn{3}{|c|}{ Haryana } & \multicolumn{3}{|c|}{ Odisha } \\
\hline & $\begin{array}{c}\text { Area } \\
(' 000 \\
\text { ha) }\end{array}$ & $\begin{array}{l}\text { Production } \\
\text { ('000T) }\end{array}$ & $\begin{array}{c}\text { Productivity } \\
\text { (tonnes/ha) }\end{array}$ & $\begin{array}{c}\text { Area } \\
\text { ('000 } \\
\text { ha) }\end{array}$ & $\begin{array}{l}\text { Production } \\
\text { ('000T) }\end{array}$ & $\begin{array}{c}\text { Productivity } \\
\text { (tonnes/ha) }\end{array}$ & $\begin{array}{c}\text { Area } \\
(' 000 \\
\text { ha) }\end{array}$ & $\begin{array}{l}\text { Production } \\
\text { ('000T) }\end{array}$ & $\begin{array}{l}\text { Productivity } \\
\text { (tonnes/ha) }\end{array}$ \\
\hline 2005-06 & 7213 & 111399 & 15.44 & 232.66 & 2984.80 & 12.83 & 629.86 & 7808.77 & 12.40 \\
\hline 2006-07 & 7581 & 114993 & 15.17 & 280.87 & 3366.86 & 11.99 & 631.62 & 7920.44 & 12.54 \\
\hline 2007-08 & 7848 & 128449 & 16.37 & 274.58 & 3277.10 & 11.93 & 660.79 & 8214.57 & 12.43 \\
\hline 2008-09 & 7981 & 129077 & 16.17 & 298.43 & 3893.43 & 13.05 & 675.95 & 8954.08 & 13.25 \\
\hline 2009-10 & 7985 & 133738 & 16.75 & 300.86 & 4020.72 & 13.36 & 694.19 & 8961.86 & 12.91 \\
\hline 2010-11 & 8495 & 146554 & 17.25 & 346.40 & 4428.90 & 12.79 & 698.63 & 9437.93 & 13.51 \\
\hline 2011-12 & 8989 & 156325 & 17.39 & 356.77 & 5068.43 & 14.21 & 690.07 & 9515.15 & 13.79 \\
\hline 2012-13 & 9205 & 162187 & 17.62 & 360.34 & 5011.31 & 13.91 & 688.15 & 9460.17 & 13.75 \\
\hline 2013-14 & 9396 & 162897 & 17.34 & 373.17 & 5565.90 & 14.92 & 677.33 & 9425.21 & 13.92 \\
\hline 2014-15 & 9542 & 169478 & 17.76 & 359.40 & 5285.59 & 14.71 & 681.34 & 9449.76 & 13.87 \\
\hline 2015-16 & 10106 & 169064 & 16.73 & 410.74 & 6156.88 & 14.99 & 652.05 & 8755.51 & 13.43 \\
\hline 2016-17 & 10238 & 178172 & 17.4 & 411.05 & 6180.43 & 15.04 & 663.86 & 8983.55 & 13.53 \\
\hline 2017-18 & 10259 & 184394 & 17.97 & 447 & 7151.7 & 16.00 & 639.7 & 8766.8 & 13.70 \\
\hline Average & 8833.69 & 149748.23 & 16.87 & 342.48 & 4799.39 & 13.82 & 667.97 & 8896.45 & 13.31 \\
\hline $\begin{array}{l}\text { Percentage } \\
\text { change } \\
\text { over } \\
2005-06\end{array}$ & 42.23 & 65.53 & 16.39 & 92.13 & 139.60 & 24.71 & 1.56 & 12.27 & 10.54 \\
\hline CAGR & 3.11 & 4.28 & 1.14 & 4.76 & 7.11 & 2.24 & 0.14 & 1.02 & 0.88 \\
\hline
\end{tabular}

(Source: National Horticulture Board, Department of Horticulture, Govt. of Haryana Department of Horticulture, Govt. of Odisha) 
Table. 3 Trends in area, production and productivity of fruits in India, Haryana and Odisha

\begin{tabular}{|c|c|c|c|c|c|c|c|c|c|}
\hline \multirow[t]{2}{*}{ Years } & \multicolumn{3}{|c|}{ India } & \multicolumn{3}{|c|}{ Haryana } & \multicolumn{3}{|c|}{ Odisha } \\
\hline & $\begin{array}{c}\text { Area } \\
(' 000 \\
\text { ha) }\end{array}$ & $\begin{array}{l}\text { Production } \\
\text { ('000T) }\end{array}$ & $\begin{array}{c}\text { Productivity } \\
\text { (tonnes/ha) }\end{array}$ & $\begin{array}{c}\text { Area } \\
\text { ('000 } \\
\text { ha) }\end{array}$ & $\begin{array}{l}\text { Production } \\
\text { ('000T) }\end{array}$ & $\begin{array}{c}\text { Productivity } \\
\text { (tonnes/ha) }\end{array}$ & $\begin{array}{c}\text { Area } \\
\text { ('000 } \\
\text { ha) } \\
\end{array}$ & $\begin{array}{l}\text { Production } \\
\text { ('000T) }\end{array}$ & $\begin{array}{c}\text { Productivity } \\
\text { (tonnes/ha) }\end{array}$ \\
\hline 2005-06 & 5324 & 55356 & 10.4 & 27.10 & 236.20 & 8.71 & 237.54 & 1403.40 & 5.91 \\
\hline 2006-07 & 5554 & 59563 & 10.72 & 30.30 & 241.92 & 7.98 & 255.60 & 1424.86 & 5.57 \\
\hline 2007-08 & 5857 & 65587 & 11.2 & 33.61 & 240.40 & 7.15 & 265.28 & 1500.78 & 5.66 \\
\hline 2008-09 & 6101 & 68466 & 11.22 & 37.61 & 262.00 & 6.97 & 289.61 & 1661.35 & 5.74 \\
\hline 2009-10 & 6329 & 71516 & 11.3 & 41.45 & 303.92 & 7.33 & 302.06 & 1845.16 & 6.11 \\
\hline $2010-11$ & 6383 & 74878 & 11.73 & 46.25 & 356.62 & 7.71 & 318.74 & 2047.68 & 6.42 \\
\hline 2011-12 & 6705 & 76424 & 11.4 & 47.04 & 476.57 & 10.13 & 326.95 & 2153.67 & 6.59 \\
\hline 2012-13 & 6982 & 81285 & 11.64 & 49.54 & 516.07 & 10.42 & 329.35 & 2210.75 & 6.71 \\
\hline 2013-14 & 7216 & 88977 & 12.33 & 50.60 & 554.90 & 10.97 & 325.85 & 2148.29 & 6.59 \\
\hline 2014-15 & 6110 & 86602 & 14.17 & 60.45 & 703.68 & 11.64 & 327.29 & 2156.49 & 6.59 \\
\hline 2015-16 & 6301 & 90183 & 14.31 & 60.92 & 737.82 & 12.11 & 340.80 & 2386.94 & 7.00 \\
\hline 2016-17 & 6373 & 92918 & 14.58 & 61.60 & 770.97 & 12.52 & 340.86 & 2430.10 & 7.13 \\
\hline 2017-18 & 6506 & 97358 & 14.96 & 64 & 793.4 & 12.40 & 340.5 & 2402.3 & 7.06 \\
\hline Average & 6287.77 & 77624.08 & 12.30 & 46.96 & 476.50 & 9.70 & 307.73 & 1982.44 & 6.39 \\
\hline $\begin{array}{l}\text { Percentage } \\
\text { change } \\
\text { over } \\
2005-06\end{array}$ & 22.20 & 75.88 & 43.85 & 136.14 & 235.90 & 42.25 & 43.34 & 71.18 & 19.42 \\
\hline CAGR & 1.41 & 4.56 & 3.11 & 7.39 & 12.90 & 5.14 & 2.87 & 5.02 & 2.09 \\
\hline
\end{tabular}

(Source: National Horticulture Board, Department of Horticulture, Govt. of Haryana Department of Horticulture, Govt. of Odisha) 
References

Anonymous.2018. Department of Horticulture, Government of Haryana.

Anonymous.2018. Department of Horticulture, Government of Odisha.

Anonymous.2018. Horticulture Statistics at a Glance. Horticulture Statistics Division, Department of Agriculture, Cooperation and Farmers Welfare, Ministry of Agriculture and Framers Welfare, New Delhi.

Chand R Prasanna L and Singh A. 2011. Farm size and productivity: Understanding the strengths of small holder and improving their livelihoods. Economic and Political Weekly, 46(2627): 5-11.

Chand, R., Raju, S.S. and Pandey, L.M. (2008). Progress and Potential of Horticulture in India. Indian Journal of Agricultural Economics, 63(3): 299-
309.

Jha, G. K., Suresh, A., Punera, B., and Supriya, P. (2019). Growth of horticulture sector in India: Trends and prospects. Indian Journal of Agricultural Sciences, 89 (2): 314-321.

Nabi, T. and Bagalkoti, S.T. (2017). Growth trends of horticulture crops in India. International Journal of Multidisciplinary Research and Development, 4(3): 158-164.

Sharma, P. and Nandal, S. (2019). Growth Pattern and Trends in Area, Production and Productivity of Selected Vegetables in India and Haryana Level. Journal of Advances and Scholarly Researches in Allied Education, 16(4):1146-1148.

Tuteja, U. (2011). Impact of the National Horticulture Mission (NHM) Scheme in Haryana. Agricultural Economics Research Centre, Pp. 3-42.

\section{How to cite this article:}

Mousumi Priyadarshini, KK Kundu and Dalip Kumar Bishnoi. 2020. Growth Trends in Area Production and Productivity of Total Horticultural Crops in India (Haryana and Odisha states). Int.J.Curr.Microbiol.App.Sci. 9(07): 3658-3661. doi: https://doi.org/10.20546/ijcmas.2020.907.428 